\title{
EDITORIAL SECTION
}

\section{Opening Address by the President of the Swiss Confederation at the Inauguration of the International Academy of Environment*}

T must admit that I feel it a real pleasure to be inaugurating the International Academy of Environment 1 here in Geneva today! Heaven knows, this is not the first time I find myself taking the floor on subjects pertaining to the international affairs of the environment. ${ }^{\dagger}$ But too often, I do so merely to make comments on a draft ministerial statement, or to announce the proposal of a convention, make a declaration of intent of a project, or merely launch an idea.

Today, the situation is different, because we are endorsing an ambitious project that has at last become a reality: the International Academy of Environment. This institution, which has required the mobilization of so much goodwill yet owes its existence to the University of Geneva, and more specifically to Professor Bernard Giovannini, is the happy endorsement of an initiative which had already been the subject of discussion for several years at the highest level within the United Nations Environment Programme (UNEP). ${ }^{\dagger}$ May I therefore express my heartfelt congratulations to all those who have contributed to the setting up of this Academy - in particular to the Canton of Geneva, the University, and of course Professor Bernard Giovannini, to whom I wish to pay a special tribute.

\section{Innovative Nature of the Academy}

Let us dwell briefly on three essential characteristics of the International Academy of Environment, ${ }^{* *}$ which I feel should be prominent in our approach if our endeavours are to meet with some measure of success as we face the ecological challenges of the 1990s.

- First of all, interdisciplinarity: after all, this is the very basis of the Academy, whose Founders have understood the need, at least in the field of environment, to reach out beyond the traditional partitioning of scientific disciplines. The environment is entirely interrelated: so how can such a complex system be fathomed if not through interdisciplinarity, which is the only possible means of achieving a global approach and hence a properly-weighed decision!

- Secondly, cooperation: could the Academy have been created without it? For the institution I have the honour to be inaugurating today is, first and foremost, the result of the solidarity prevailing between the Federal and Cantonal Authorities, the international organizations, the private sector, and the nongovernmental organizations. The joint understanding of these different partners, which in many ways is exemplary, seems to me to be worthy of becoming a principle for the future. We will either solve the environmental problems together or we will fail to solve them altogether!

- Thirdly, openness: no other institution than an Academy has a greater vocation to be open to the outside world - particularly to the developing countries and those of Eastern Europe. Besides, what better proof of this openness could we have than the presence, by my side, of HE José Goldemberg, Minister for Science and Technology of Brazil?

Interdisciplinarity, cooperation, and openess are, therefore, the three principles and steps which will enable the Academy to perform its two main functions best, namely (1) to bridge the gap between the different yet complementary fields and disciplines, and (2) to assist, if not enlighten, those decision-makers who wish to understand the environment better in order to include due attention to it in their daily life and activities.

\section{The Need for International Action}

Just now I referred to the ecological challenges which we have to face in the next decade: these include the struggle against the expected change in climate, the impoverishment of biodiversity as well as that of water resources which continue to diminish, the deterioration of the stratospheric ozone shield, the destruction of tropical forests, and many others. The list of combats to be waged is already too long for me

\footnotetext{
* Delivered in French on the morning of 24 June 1991 in the grounds of the Academy's Headquarters, 4 Chemin de Conches, 1231 Conches, Geneva, Switzerland, following an inaugural meeting of the Governing Council of the Academy in its Library at the same address; our warm thanks are due to Mrs Enid Nekrouf for help with this rendering, and to President Cotti for his kind permission to publish it. - Ed.

${ }^{\dagger}$ Here we should explain that His Excellency is also Minister of Environment, Forests and Landscape, in the Federal Government of Switzerland. - Ed.

$\dagger^{\dagger}$ Your Editor can only presume that this refers to the interest (expressed earlier more than once in his hearing) of Dr Mostafa K. Tolba, Executive Director of the United Nations Environment Programme, in ultimately seeing into being some such world-collating environmental body as we both hope ardently the new Academy will be. To such ends we are pleased and honoured to serve on its Governing Council. - Ed.

** Now regularly omitting, as we suggested early-on, any penultimate article from the title — so as to dignify Environment as a study in its own right, rather than merely 'something around us'. - Ed.
} 
to cite all of them. But we are aware that we do need combined international action, as will surely be confirmed at the United Nations Conference on Environment \& Development (UNCED), which will be held next June in Rio de Janeiro, Brazil.

\title{
Actions by Switzerland
}

Here I would like to give two examples which I feel are significant and show the will of our country not to remain idle in the face of the dangers that threaten us:

- First of all, at the beginning of the year - a rather special year because this is the 700th Anniversary of the Swiss Confederation - Parliament approved the granting of two new subsidies.

- On one hand, a major subsidy for 400 million francs to assist certain impoverished developing countries to begin to pay or hasten the payment of their debts.

- On the other hand, a credit of 300 million francs to finance projects, in the developing countries, to foster the global environment. This sum is, more specifically, additional to the funds which are allocated for aid for development, and will be exclusively earmarked for measures to protect the global environment. This credit should thus contribute to the protection of the ozone layer, to the struggles against climatic change, to the preservation of biodiversity, to safeguarding tropical forests or, as well, to organize a rational management of toxic products and wastes. Switzerland, I am happy to say, has therefore taken the step enabling the concept of 'additionality', which has been used for some time in international debates, to become a fact.

Then - and this is a second example of Switzerland's action, in the international field, in favour of the environment - there is the implementation of a programme of cooperation with the countries of Central and Eastern Europe, which, as we must all be aware, are also partners, perforce, in the settlement of global environmental problems. Thus, last year, Parliament set aside a credit of 250 million francs, to be used over a two-years' period, for this cooperation, a substantial proportion of which - 30 million francs - was earmarked for the environment.

Currently a new message is being drafted, and if it is approved by Parliament, it will first enable the strengthening of the programmes already launched (for example with Czechoslovakia, Hungary, and Poland) in fields such as management of toxic wastes and the rehabilitation of forests, and then will extend this cooperation to a larger number of countries - in particular, the Soviet Union.

There can be no doubt that the International Academy of Environment will have its part to play among those teaming activities - by fostering dialogue, stimulating exchange of information, and usefully bringing together, in a productive manner, scientific research workers and their various fields.

\section{Conclusion: The Role of Geneva}

I would not like to conclude without saying a few words about the international calling of Geneva. The name, Geneva, has often been associated, at least latterly, with the environment. This association will not fail to be even more prevalent in the future, thanks to steps taken by the Cantonal and Municipal Authorities, whom I congratulate on their dynamism and efficiency.

The environmental institutions and programmes which have chosen to establish their headquarters in Geneva become more and more numerous every year. Today, with the inauguration of the International Academy of Environment, Geneva is further strengthening its position and image - and thereby that of our entire country. Will Geneva become the future capital of the environment? That was the hint I received in Berne, and, believe me, it did not displease me any more than it should you.

\author{
Flavio CotTI, Federal Councillor \& Minister \\ President of the Swiss Confederation \\ Federal Office of Environment, Forests, and Landscape \\ Hallwylstrasse 4 \\ 3003 Berne, Switzerland.
}

